\title{
Study of the service functions of health facilities in Yogyakarta Special Province
}

\author{
Mohammad Isnaini Sadali ${ }^{1}$, Raden Rijanta ${ }^{2}$, Lutfi Mutaali ${ }^{2}$, and Andri Kurniawan ${ }^{2}$ \\ ${ }^{1}$ Doctoral Program, Faculty of Geography, Universitas Gadjah Mada, Yogyakarta, Indonesia \\ ${ }^{2}$ Department of Development Geography, Faculty of Geography, Universitas Gadjah Mada, Yogyakarta, Indonesia
}

\begin{abstract}
The provision of public service facilities in settlement and regional environments is the right of the community to support a decent life and livelihood also to improve the quality of life. Therefore, the availability of health facilities must be considered so that every Indonesian can obtain their right to health services. This study aims to analyze the availability of health service facilities and the service function of health facilities in Yogyakarta Special Province. As a differentiator with previous research, the researcher conducted a analyze comprehensively by combining analysis of the centrality index and the service function to determine the hierarchy of health service centers. The location of this research is in the Yogyakarta Special Province with the smallest area analysis unit is the sub-district. The results showed that the availability of low order goods health service facilities was generally fulfilled in all sub-districts of Yogyakarta Special Province. Cities are still areas of high concentration of health services, this is reinforced by the highest centrality index and hierarchy of health facilities in Yogyakarta City.
\end{abstract}

\section{Introduction}

In accordance with the mandate of The 1945 Constitution (UUD) and Article $28 \mathrm{H}$ of the Amendment of 1945 Constitution (UUD), health services are one of the basic rights of every Indonesian, so every citizen has the right to get good and decent health services. The existence of health service facilities affects the public health status of a country. Law Number 36 of 2009 concerning Health explains that a health service facility is a tool and/or place used to carry out health service efforts, whether promotive, preventive, curative, or rehabilitative carried out by the government, local government, and/or the community [9].

Indonesia's total population in 2019 reaches $268,074,565$ people [4] and requires facilities and health personnel as many as possible so that they can be evenly distributed throughout the region [12]. Based on The Minister of Health Regulation Number 75 of 2014 concerning Puskesmas (Community Health Centre), every Puskesmas in 2019 can provide services according to standards [10]. Therefore, it is necessary to increase health services in terms of the number and types of health facilities, health human resources, health financing, and disease control. The distribution of medical personnel and health facilities such as Puskesmas and hospitals is currently still piling up in the city. The central area of activity is the central of regional activity including service facilities (including health facilities) tend to be more complete in cities [1]. The high number of Puskesmas in each region cannot guarantee whether these facilities are adequate to support public health in the regions.
The commitment of the Indonesian Government in providing more adequate health services for the community in the next 5 years is demonstrated by the implementation of the National Health Insurance by BPJS Kesehatan (Health Social Security Agency). This policy needs to be balanced with monitoring and evaluation to ascertain whether the National Health Insurance policy by BPJS Kesehatan can improve the both quality of health services and access to reach them for all Indonesian citizens with the principle of justice [2][11]. The government has 3 (three) basic plans, namely: development of health personnel from 2011 to 2025, improvement of the BPJS system which is currently still under development, and expansion of health infrastructure. The availability of health insurance (insurance) must be balanced with good health quality [15].

In order to strengthen primary health services, there are three indicators related to the implementation of Puskesmas in the 2015-2019 RPJMN and the Ministry of Health's Strategic Plan 2015-2019, namely: 1) SubDistricts that have at least 1 accredited Puskesmas; 2) the number of non-inpatient Puskesmas and in-patient Puskesmas that provide services according to standards; and 3) the number of Puskesmas in cooperation with the Blood Transfusion Unit and hospitals in providing blood services to reduce the Maternal Mortality Rate (MMR). Through the strengthening of primary health services, it is hoped that it will be able to improve the level of public health in each region. Of course, human resource support and health infrastructure are needed to achieve these targets.

One of the health efforts made by the Provincial Health Office of the Yogyakarta Special Province 
(DIY) in carrying out its duties and functions is basic health services and referrals. Basic health service facilities are carried out by the Puskesmas and equal health facilities, while referral health services are managed by the Hospital. There are 121 Puskesmas in DIY, consisting of 45 nursing and 76 non-nursing public health centres [5]. In 2019, the achievement of improving the quality of health facilities in DIY was shown by the accreditation of all Puskesmas. The highest number of Puskesmas that provides nursing is in Bantul Regency (17 Puskesmas), while the smallest is in Yogyakarta City (2 Puskesmas). Yogyakarta City has a very close distance between Puskesmas and there are several hospitals that provide nursing facilities so that the Puskesmas that provide nursing in Yogyakarta City is deemed unnecessary. Meanwhile, the access and distance of several areas in Bantul Regency are quite far from the hospital, so that a Puskesmas with provide nursing is needed.

This research was started by identifying the number and mapping the existence of health service facilities in Yogyakarta Special Province so that the distribution could be seen for the sake of further analysis. The existence of health service facilities in Yogyakarta Special Province needs to be analyzed the level of availability and the function of its services to ensure public access to health services. This study seeks to provide an explanation regarding the distribution of health service facilities in Yogyakarta Special Province and to compare the service functions of health facilities in each region.

\section{Method}

This research uses quantitative research methods, with secondary data as the main data and the analysis is carried out in an explanative manner. The research location is administratively located in the Yogyakarta Special Province. Some of the main secondary data collected to support this research are:

- Total population.

- Number and types of health service facilities in 2015 and 2019.

- Regency and City in Figures in 2015 and 2019.

- Yogyakarta Special Province (DIY) Health Profile.

- Planning documents.

The determination of the 5-year period (2014-2019) in this analysis refers to the issuance of The Minister of Health Regulation Number 75 of 2014 which has a target that in 2019 health services can meet the standards and the numbers meet the needs of the community. Analysis of service functions can be seen from the comparison between the availability of health service facilities and comparison variables. This can be seen from the size of actual users, potential users, total population, and by standard comparisons. The number of units and types of health service facilities in DIY is considered as the principle of serviceability (threshold). This principle is conceptually referred to from the theory of the central place presented by Christaller, 1933 [6]. The standard of serviceability of health facilities in Indonesia refers to the Minister of
Public Works Regulation No. 41/PRT/M/2007 concerning Guidelines for Technical Criteria for Cultivated Areas and SNI 03-1733-2004 on Procedures of Planning for Housing Environment in Urban Areas.

The basis for providing health facilities is the number of people served by health facilities. The basis for this provision will also consider the spatial approach of the existing environmental units or groups. Of course, this can be related to the formation of building groups/blocks which will be formed according to the context of the environment. Whereas the placement of the provision of health facilities [7] will consider the reach of the service area radius related to the basic needs of health facilities that must be met to serve in certain areas. Table 1 shows the minimum population to support the provision of a health facility in the region The greater the serviceability of the facility, the greater the minimum population requirement (threshold) that must be met.

Table 1. Total Population Supporting Health Facilities

\begin{tabular}{|c|c|}
\hline Type of Health Facility & $\begin{array}{c}\text { Number of Supporting } \\
\text { Population }\end{array}$ \\
\hline Hospital & 240.000 \\
\hline Maternity Hospital & 30.000 \\
\hline Polyclinic & 30.000 \\
\hline $\begin{array}{c}\text { Puskesmas (Community } \\
\text { Health Centre) }\end{array}$ & 120.000 \\
\hline Supporting Puskesmas & 30.000 \\
\hline Pharmacy & 30.000 \\
\hline $\begin{array}{c}\text { Posyandu (Integrated } \\
\text { Health Centre) }\end{array}$ & 1.250 \\
\hline
\end{tabular}

Note: Reference is taken from SNI 03-1733-1989, Planning Procedures for Urban Housing Areas.

Source: SNI 03-1733-2004, Procedures of Planning for Housing Environment in Urban Areas.

\section{Result}

\subsection{Availability of Health Service Facilities in Yogyakarta Special Province}

Regional development as a central activity will be oriented towards providing infrastructure or supporting facilities in it capable of supporting the activities of the area [3]. The availability of health facilities is needed to provide health services to the community and has a very strategic role in accelerating the improvement of public health status as well as controlling population growth. The government needs to encourage the improvement of the quality of health service facilities, both public and private health facilities in order to meet the expectations and needs of the community [13]

The availability of health facilities in DIY can be measured by looking at the availability of hospital facilities, maternity hospitals, polyclinics, health centres, auxiliary health centres, pharmacies, and Posyandu. The suitability of the availability of health facilities is measured by considering the number of residents and existing health facilities. Measurement of 
the availability of health facilities in DIY is also carried out between 2015 and 2019 so that progress could be seen. There are three categories of suitability for the availability of health facilities, namely: highly fulfilled, fulfilled, and unfulfilled. The highly fulfilled category is obtained if the number of existing health facilities exceeds the ideal number of health facilities. Fulfilled categories are obtained if the number of existing health facilities is the same as the ideal number of health facilities. The unfulfilled category is obtained if the number of existing health facilities is less than the ideal number of health facilities.

The sub-districts in regency/city which are predominantly rural-urban have a better level of availability of health facilities. For example, the availability of maternity hospitals in sub-districts in Gunungkidul has a "not fulfilled" category. On the other hand, the availability of maternity hospitals in the sub-districts in the Yogyakarta City has been "fulfilled" and even "highly fulfilled". Apart from the rural-urban category, the difference in the level of availability of health facilities can also be seen from the types of facilities. Health facilities with a higher level of service (high order goods services), such as hospitals and maternity hospitals, are generally not fulfilled according to regional needs. Meanwhile, the availability of health facilities with a lower level of service (low order goods services) such as Puskesmas, pharmacies, and Posyandu, tends to exceed the ideal number required by the regions.

The development of the availability of health facilities in DIY from 2015 to 2019 was volatile. Generally, there has been a decrease in the number of low-order health facilities such as Posyandu, but they still meet their ideal needs. On the other hand, there has been an increase in the number of higher order health facilities such as hospitals and maternity hospitals. The amount of increase is not significant but is able to meet the ideal need for health facilities in the area. Fig. 1 shows a number of sub-districts which meet the ideal number of health facilities in each regency/city in DIY. In general, a number of sub-districts that do not meet the ideal number of health facilities are always smaller than the number of sub-districts that do or are highly fulfilling.

Based on the type of health facilities, regency/city that meet the ideal number of hospital facilities are Yogyakarta City, Bantul Regency, Kulon Progo Regency, and Gunungkidul Regency. Meanwhile, in Sleman Regency, there are still 2 sub-districts that do not meet the ideal number of hospitals. Furthermore, districts/cities that meet the ideal number of maternity hospitals are Yogyakarta City, Sleman Regency, Bantul Regency, and Kulon Progo Regency, while Gunungkidul Regency does not meet the ideal number of maternity hospitals needed at all. The availability of many polyclinics does not meet the ideal number of needs per sub-district, including 2 sub-districts in Yogyakarta City, 6 sub-districts in Sleman Regency, 4 sub-districts in Bantul Regency, 5 sub-districts in Kulon Progo Regency, and 2 sub-districts in Gunungkidul Regency. Details of the classification of the suitability of the availability of health facilities and their distribution in the districts/cities of Yogyakarta Special Province according to the type of facilities can be seen in Table 2 .

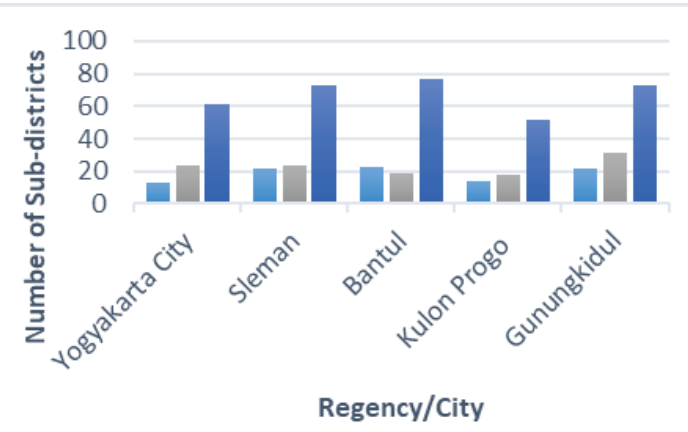

Not Fulfilled $\mathbf{a}$ Fulfilled $\mathbf{n}$ Highly Fulfilled

Fig. 1. Graph of the Number of Sub-districts that Meet the Ideal Number of Health Facilities in DIY in 2019

$$
\text { Source: Secondary Data Analysis, } 2020
$$

Table 2. Sub-districts that Meet the Ideal Number of Health Facilities in Yogyakarta Special Province in 2019

\begin{tabular}{|l|c|c|c|c|c|c|c|c|c|}
\hline \multirow{2}{*}{$\begin{array}{c}\text { Type } \\
\text { Facilities }\end{array}$} & \multicolumn{3}{|c|}{$\begin{array}{c}\text { Yogyakarta } \\
\text { City }\end{array}$} & \multicolumn{4}{c|}{ Sleman } & \multicolumn{3}{c|}{ Bantul } \\
\cline { 2 - 11 } & NF & F & HF & NF & F & HF & NF & F & HF \\
\hline Hospitals & 0 & 6 & 8 & 2 & 13 & 2 & 0 & 8 & 9 \\
\hline $\begin{array}{l}\text { Maternity } \\
\text { Hospitals }\end{array}$ & 4 & 7 & 3 & 12 & 3 & 2 & 16 & 0 & 1 \\
\hline Polyclinic & 2 & 5 & 7 & 6 & 3 & 8 & 4 & 5 & 8 \\
\hline Puskesmas & 0 & 1 & 13 & 0 & 2 & 15 & 0 & 0 & 17 \\
\hline $\begin{array}{l}\text { Supporting } \\
\text { Puskesmas }\end{array}$ & 7 & 5 & 2 & 1 & 3 & 13 & 1 & 3 & 13 \\
\hline Pharmacies & 0 & 0 & 14 & 0 & 0 & 17 & 0 & 3 & 14 \\
\hline Posyandu & 0 & 0 & 14 & 1 & 0 & 16 & 2 & 0 & 15 \\
\hline Total & 13 & 24 & 61 & 22 & 24 & 73 & 23 & 19 & 77 \\
\hline
\end{tabular}

\begin{tabular}{|l|c|c|c|c|c|c|}
\hline \multirow{2}{*}{ Type Facilities } & \multicolumn{3}{|c|}{ Kulon Progo } & \multicolumn{3}{c|}{ Gunungkidul } \\
\cline { 2 - 7 } & NF & F & HF & NF & F & HF \\
\hline Hospitals & 0 & 6 & 6 & 0 & 14 & 4 \\
\hline $\begin{array}{l}\text { Maternity } \\
\text { Hospitals }\end{array}$ & 6 & 5 & 1 & 18 & 0 & 0 \\
\hline Polyclinic & 5 & 5 & 2 & 2 & 6 & 10 \\
\hline Puskesmas & 0 & 0 & 12 & 0 & 0 & 18 \\
\hline $\begin{array}{l}\text { Supporting } \\
\text { Puskesmas }\end{array}$ & 0 & 0 & 12 & 0 & 0 & 18 \\
\hline Pharmacies & 3 & 2 & 7 & 2 & 11 & 5 \\
\hline Posyandu & 0 & 0 & 12 & 0 & 0 & 18 \\
\hline Total & 14 & 18 & 52 & 22 & 31 & 73 \\
\hline
\end{tabular}

Information: Not Fulfilled (NF); Fulfilled (F); Highly Fulfilled (HF)

Source: Secondary Data Analysis, 2020

The need for health facilities at a lower level/order of service (low order goods services), such as Puskesmas, has been met in every sub-district in DIY. However, some of The Supporting Puskesmas are still not fulfilled, namely 7 sub-districts in Yogyakarta City, 
1 sub-district in Sleman Regency, and 1 sub-district in Bantul Regency. Pharmacy facilities are still not fulfilled in several sub-districts, namely 3 sub-districts in Kulon Progo Regency and 2 sub-districts in Gunungkidul Regency. Then, the availability of Posyandu facilities tends to exceed the ideal number needed in each sub-district. The availability of health facilities greatly determines the coverage of health services. Variations in the level of health facilities (primary, secondary and tertiary) and the range/coverage of health services can ensure good quality health services [17].

\subsection{Service Functions of Health Facilities in DIY}

The analysis used to explain the service functions of health facility is the centrality index and the hierarchy of service functions. The Centrality Index is used to see the service capability of a centre in terms of a number of health facility units in the service centre. The centrality index analysis takes into account a number of health facility units, so the assumption used is that the region with the most health facility units is the highest order and is designated as a health service centre. The Centrality Index not only looks at a number of functions or facilities, but also based on the frequency of the existence of health functions or facilities.

The service function of health facilities provides an indication of the quality and adequacy of services, so that the better the serviceability, the better the quality of the facilities. In addition, the service function is also able to show the allocation of space or areas in need of health facilities based on a number of inhabitants. The hierarchy of the health facilities service centre is measured using the cumulative value of the centrality index and service function. There are three hierarchies that describe the structure or hierarchy of health service centres in an area, how many functions there are, how many types of functions are served and how many people are served, and how much is the frequency of the existence of a function in a residential area. Hierarchy I is the centre of health area, while hierarchy II and III act as a hinterland [8]. Below (Table 3 and Table 4) are the results of the analysis of the hierarchy of health service centres in DIY.

Table 3. Hierarchy of Health Facilities Service Centres by Regency/City in DIY Province in 2015

\begin{tabular}{|l|r|r|r|c|}
\hline $\begin{array}{c}\text { Regency/ } \\
\text { City }\end{array}$ & $\begin{array}{c}\text { Centrality } \\
\text { Index }\end{array}$ & $\begin{array}{c}\text { Service } \\
\text { Function }\end{array}$ & $\begin{array}{c}\text { Cumulative } \\
\text { (IS+SF) }\end{array}$ & $\begin{array}{c}\text { Hierar- } \\
\text { chy }\end{array}$ \\
\hline Bantul & 6.29 & 2.64 & 8.92 & II \\
\hline Kulon Progo & 5.43 & 1.76 & 7.19 & II \\
\hline Gunungkidul & 2.14 & 1.13 & 3.27 & III \\
\hline Sleman & 5.54 & 3.36 & 8.90 & II \\
\hline Yogyakarta & 98.02 & 22.68 & 120.70 & I \\
\hline
\end{tabular}

Table 4. Hierarchy of Health Service Centre Facilities by Regency/City in DIY Province in 2019

\begin{tabular}{|c|c|c|c|c|}
\hline $\begin{array}{c}\text { Regency/ } \\
\text { City }\end{array}$ & $\begin{array}{c}\text { Centrality } \\
\text { Index }\end{array}$ & $\begin{array}{c}\text { Service } \\
\text { Function }\end{array}$ & $\begin{array}{c}\text { Cumulative } \\
\text { (IS+SF) }\end{array}$ & $\begin{array}{c}\text { Hierar- } \\
\text { chy }\end{array}$ \\
\hline
\end{tabular}

\begin{tabular}{|l|r|r|r|c|}
\hline Bantul & 6.29 & 2.67 & 8.96 & II \\
\hline Kulon Progo & 5.43 & 1.85 & 7.28 & II \\
\hline Gunungkidul & 2.14 & 1.11 & 3.26 & III \\
\hline Sleman & 5.54 & 3.41 & 8.96 & II \\
\hline Yogyakarta & 98.02 & 22.62 & 120.64 & I \\
\hline
\end{tabular}

Source: Secondary Data Analysis, 2020

At the provincial level, Yogyakarta City is a health service centre (hierarchy I) with a cumulative value of 120.64 in 2019. Sleman Regency, Bantul Regency, and Kulon Progo Regency are included in hierarchy II hinterlands with each cumulative value of the centrality index and service function in in 2019, namely 8.96; 8.96; and 7.28. Last, Gunungkidul Regency is included in the hinterland hierarchy III, with a cumulative value that is much lower than the hierarchy I service centre, which is only 3.26 in 2019. Observed from a number of types and health facility units, it can be said that each regency/city has a complete range of 7 types of health facilities including hospitals, maternity hospitals, polyclinics, Puskesmas, Supporting Puskesmas, pharmacies, and Posyandu. However, when viewed from a number of health facility units, the higher the hierarchy of health service centres, the higher the number of health facility units available. The difference in the cumulative value of the centrality index and the service functions of health facilities is very significant between the service centre and its hinterland, indicating inequality in development, especially related to the availability of health facilities. There are a few things that cause inequality in health facilities in the regional are the availability, geographic conditions, population distribution, as well as regional policy [14]. The cumulative value of the centrality index and service function from 2015 to 2019 also does not show any significant development for the hinterland area to approach the order of health service centres.

A review of the results of the analysis of the service functions of health facilites at the regency/city level is able to show the sub-districts that play a role as a health service centre and its hinterland. Yogyakarta City as a provincial health service centre has a cumulative value for the Centrality Index and Service Function of each sub-district in the range 17.43 to 68.05 in 2019. Sub-districts with hierarchy I health service status are Danurejan (68.05); Ngampilan (66.90); Pakualaman (65.99); and Gedongtengen (58.93). Sub-districts with hierarchy II health service status are Kraton hierarchy (47.55); Gondoamanan (43.47); Wirobrajan (43.47); Mergangsan (41.50); Jetis (38.36); and Mantrijeron (35.58). Then, Sub-districts with hierarchy III health service status are Tegalrejo (30.76); Gondokusuman (27.53); Kotagede (25.48); and Umbulharjo (17.43). The sub-district that experienced an increase hierarchy was only Gedongtengen. It was in hierarchy II in 2015 then became in hierarchy I in 2019 and there were no subdistricts that experienced decrease hierarchy (see Fig. 2). 


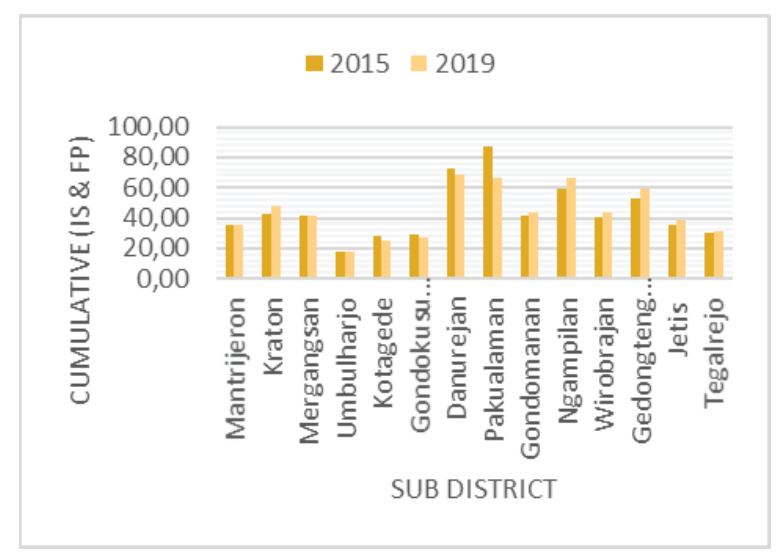

Fig. 2. Graph of Cumulative Value (Centrality Index and Service Function) of Health in Yogyakarta City

Sleman Regency has the cumulative value of the Centrality Index and Service Function of each subdistrict in the range of 10.37 to 25.63 in 2019 (see Fig. 3). Sub-districts with hierarchy I health service status are Gamping (25.63); Berbah (24.91); Mlati (24.82); and Sleman (19.72). In the hinterland hierarchy II, there are Godean (19.02); Seyegan (18.05); Ngemplak (17.75); Moyudan (17.73); Ngaglik (17.07); Depok (16.64); and Tempel (16.58). Then, sub-districts with the hinterland hierarchy III are Minggir (14.91); Kalasan (14.86); Prambanan (14.24); Turi (11.85); Pakem (11.69); and Cangkringan (10.37). In 20152019, the sub-district that experienced an increase hierarchy from hierarchy III to hierarchy II was Ngemplak. There are also sub-districts that experienced the increase hierarchy from hierarchy II to hierarchy I, namely Berbah and Sleman. Sub-districts that experienced decrease hierarchy from hierarchy II to hierarchy III were Minggir and Kalasan, then Subdistricts that experienced decrease hierarchy from hierarchy I to II were Moyudan, Seyegan, and Godean.

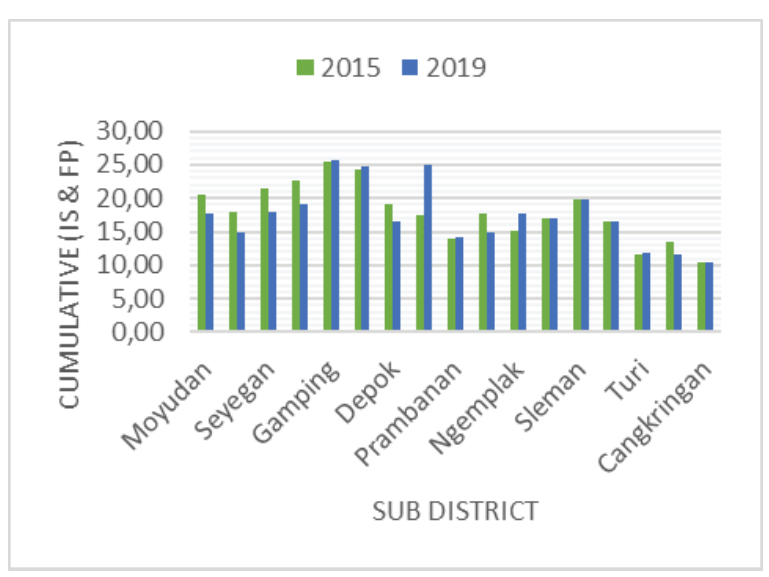

Fig. 3. Graph of Cumulative Value (Centrality Index and Service Function) of Health Facilities in Sleman Regency

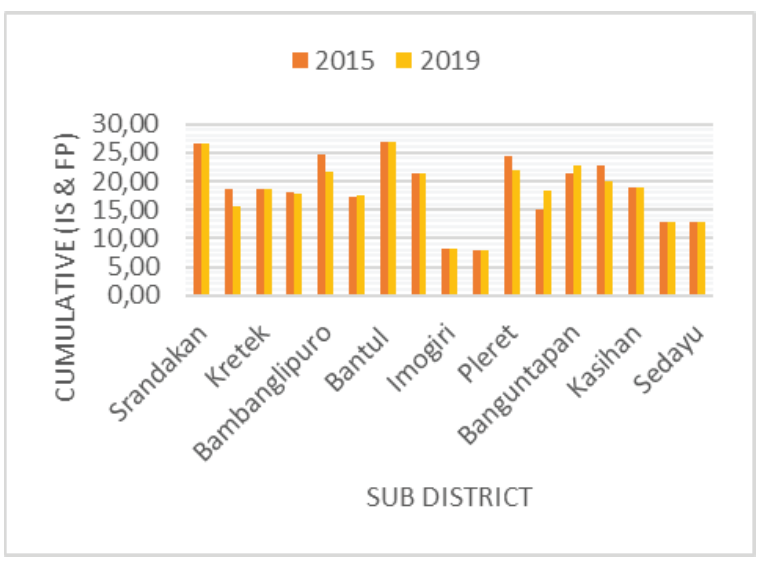

Fig. 4. Graph of Cumulative Value (Centrality Index and Service Function) of Health in Bantul Regency

Fig. 4 above shows that Bantul Regency has the cumulative value of the Centrality Index and Service Function of each sub-district in the range of 7.88 to 26.83 in 2019. Sub-districts with hierarchy I health service status are Bantul (26.83); Srandakan (26.55); Banguntapan (22.71); Pleret (21.92); Bambanglipuro (21.61); and Jetis (21.35). In hinterland hierarchy II, there are Sewon (19.86); Kasihan (18.83); Kretek (18.66); Piyungan (18.22); Pundong (17.86); Pandak (17.45); and Sanden (15.52). Then, sub-district in hierarcy III are Pajangan (12.96); Sedayu (12.81); Imogiri (8.30); and Dlingo (7.88). In 2015-2019 the sub-district that experienced an increase hierarchy from hierarchy III to hierarchy II was Piyungan. There were also sub-districts that had increased hierarchy from hierarchy II to hierarchy I, namely Jetis and Banguntapan. The sub-district that experienced a decreased hierarchy from hierarchy I to hierarchy II was Sewon.

Kulon Progo Regency has the cumulative value of the Centrality Index and Service Function of each subdistrict in the range of 4.45 to 20.95 in 2019 (Fig. 5). Sub-districts with hierarchy I health service status are Wates (20.95); Temon (19.24); Lendah (18.58); Galur (17.85); and Nanggulan (16.54). In the hinterland hierarchy II, there are Panjatan (13.87) and Sentolo (11.52). Then, sub-districts with the hinterland hierarchy III are Kalibawang (9.61); Pengasih (8.33); Samigaluh (7.75); Girimulyo (5.72); and Kokap (4.45). In 2015-2019 the sub-district that experienced an increase hierarchy from hierarchy II to hierarchy II was Sentolo. The sub-district that experienced a decreased hierarchy from hierarchy II to hierarchy III was Kalibawang. 


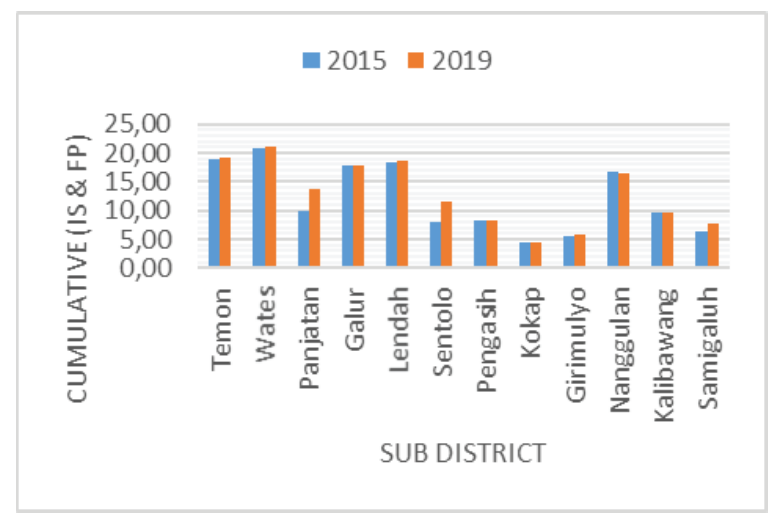

Fig. 5. Graph of Cumulative Value (Centrality and Service Function Index) of Health Facilities in Kulon Progo Regency

The range of cumulative values for the Centrality and Service Function Index for each sub-district in Gunungkidul Regency is 9.32 to 24.43 in 2019 (see Fig. 6). Sub-districts with hierarchy I health service status are Ngawen (24.43); Wonosari (21.53); Paliyan (19.10); Semin (17.92); and Karangmojo (17.45). Subdistricts with hierarchy II are Patuk (15.88); Nglipar (15.24); Rongkop (14.01); Gedangsari (13.56); Playen (13.24); Tanjungsari (12.92); and Saptosari (12.84). Then, sub-districts with hierarchy III are Purwosari (12.36); Girisubo (12.21); Bake (11.19); Tepus (11.00); Semanu (10.89); and Ponjong (9.32). In 2015-2019 the sub-districts that experienced the increase hierarchy from hierarchy III to hierarchy II were Saptosari and Rongkop. There was also sub-district that experienced an increase hierarchy from hierarchy II to hierarchy I, namely Semin. Then, the sub-district that experienced a decrease hierarchy from hierarchy II to hierarchy III was Semanu.

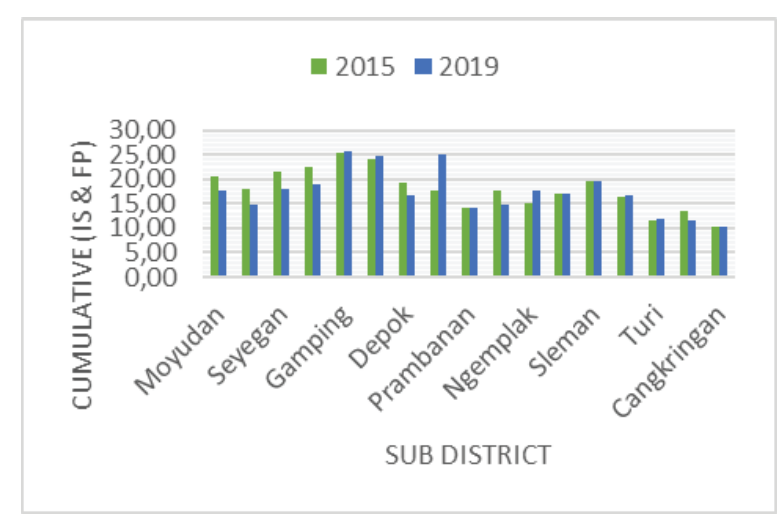

Fig. 6. Graph of Cumulative Value (Centrality Index and Service Function) of Health Facilities in Gunungkidul Regency

\section{Closing}

The provision of health service facilities in residential area and regional is the right of the community to support a decent life and livelihood for the sake of improving the quality of life. The suitability between the availability and regional basic needs of service facilities can be one of the benchmarks for the success of regional development. The provision of health facilities in Indonesia currently uses population size as a comparison variable (ratio of health facilities and total population). Thus the minimum need for health facilities can be determined by considering serviceability.

The results showed that there were health facilities with a higher level of service (high order goods services) that were not fulfilled according to regional needs. Meanwhile, health facilities with a lower level of service (low order goods services) such as Puskesmas, pharmacies, and Posyandu tend to exceed the ideal number required by the region. The city centre is still the centre for regional health services. This is indicated by the high index of centrality and service function in the Yogyakarta City, so that it is included in hierarchy I (the highest). Sleman Regency, Bantul Regency, and Kulon Progo Regency are hinterland areas with hierarchy II, while Gunungkidul Regency is the area with the lowest hierarchy at the Provincial level.

This research is part of the Doctoral Dissertation of Geography Study Program, Universitas Gadjah Mada. Thanks to the promoter team who have provided input for this research, also to Rifan and Zara who have supported this research.

\section{References}

1. H. S. Yunus, Struktur Tata Ruang Kota (Pustaka Pelajar, Yogyakarta, 2002)

2. Yandrizal, D. Suryani, B. Anita, and H. Febriawati, JKKI, 3, 2 (2014)

3. M. I. Sadali, F. Intizhar and Aisyah, MKG, 18, 2 (2017)

4. Secretariat General of the Indonesian Ministry of Health, Profil Kesehatan Indonesia Tahun 2019, (Ministry of Health's, Jakarta, 2020)

5. Yogyakarta Special Region Provincial Health Office, Profil Kesehatan Daerah Istimewa Yogyakarta Tahun 2018 (Yogyakarta Special Region Provincial Health Office, Yogyakarta, 2019)

6. W. Christaller, Central Place in Southern Germany (Prentice-Hall, New Jersey, 1933)

7. K. M. Curtin and R. L. Church, JGS, 9 (2007)

8. D. Pumain, in Hierarchy in Natural and Social Sciences, edited by D. Pumain (Springer, Dordrecht, 2006), pp. 169-222

9. Republic of Indonesia, Undang-Undang Nomor 36 Tahun 2009 tentang Kesehatan (State Secretariat, Jakarta, 2009)

10. Republic of Indonesia, Peraturan Menteri Kesehatan Nomor 75 Tahun 2014 tentang Puskesmas (State Secretariat, Jakarta, 2014)

11. G. Rushton, Optimal Location of Facilities, (N.H.: COMPress, Wentworth, 1979)

12. Susilowati, Ketidakmerataan Akses Pelayanan Kesehatan Rawat Jalan di Indonesia, Doctoral 
dissertation, Universitas Gadjah Mada, Yogyakarta, 2004

13. Selma A.S. Siahaan, JPPPK, 2, 2 (2018)

14. Suman, S. Bhutani, IJARD, 2, 6 (2017)

15. S. S. Endartiwi, and P. D. Setianingrum, JIIK, 6, 1 (2019)

16. R. McCollum, M. Taegtmeyer, L. Otiso, M. Mireku, N. Muturi, T. Martineau, and S. Theobald, Int J Equity Health, 18, 65 (2019)

17. M. C. Sheff, A. A. Bawah,,P. O. Asuming, P.

Kyei, M. Kushitor, J. F. Phillips, and S. P. Kachura, Glob Health Action, 13, 1 (2020) 